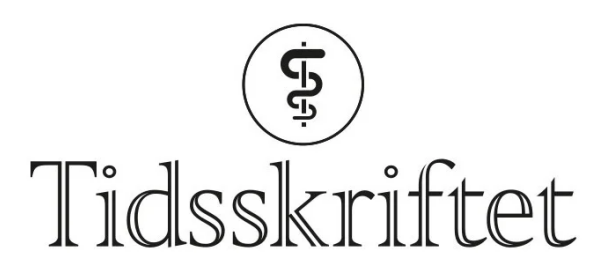

DEN NORSKE LEGEFORENING

\title{
Biologiske legemidler ved primært Sjögrens syndrom?
}

FRA ANDRE TIDSSKRIFTER

KARI TVEITO

Tidsskriftet

\section{Rituximab, et antistoff mot B-celler, hadde ingen sikker effekt ved primært Sjögrens syndrom i en randomisert, blindet studie.}

Sjögrens syndrom er en plagsom, autoimmun tilstand som er vanskelig å behandle. Det finnes i dag ingen systemisk behandling som påvirker forløpet av primært Sjögrens syndrom. Bruk av rituximab, et antistoff mot B-celler, har vist lovende resultater, og er nå undersøkt i en randomisert multisenterstudie (1).

Studien omfatter 120 pasienter fra 14 universitetssykehus i Frankrike. Sykdomsgrad ble målt ved bruk av fire VAS-skalaer for global sykdom, smerte, utmattelse (fatigue) og tørre slimhinner. Pasientene ble randomisert til to infusjoner, gitt med to ukers mellomrom, med rituximab eller placebo. Seks måneder senere var det ingen forskjell mellom gruppene i primært endepunkt, som var andel pasienter som oppnådde en forhåndsdefinert reduksjon i minst to VAS-skalaer. Rituximabgruppen hadde imidlertid signifikant reduksjon i VAS-skår samt mindre sykdomsaktivitet vurdert av lege etter seks uker og redusert utmattelse etter både seks og 16 uker.

- Det er en god studie fordi den er blindet og omfatter mange pasienter fra flere sentre, sier Roald Omdal, spesialist i indremedisin og revmatologi og professor ved Stavanger universitetssjukehus. - Svakheten er at effekten ble evaluert seks måneder etter bare to infusjoner med rituximab. Tilsvarende studiedesign og effektmål er blitt kritisert i studier ved systemisk lupus erythematosus, der man heller ikke så noen effekt av rituximab. Ved begge disse sykdommene viser klinisk erfaring at rituximab kan ha effekt, og andre studier peker i denne retningen.

- At pasientene i denne studien følte seg mindre utmattet i noen måneder, passer godt med studier der biologiske legemidler er brukt mot autoimmune og inflammatoriske sykdommer. Virkningsmekanismen kan være at midlene reduserer utskilling av proinflammatoriske cytokiner, sier Omdal. 
LITTERATUR

1. Devauchelle-Pensec V, Mariette X, Jousse-Joulin S et al. Treatment of primary Sjögren Syndrome with rituximab. A randomized trial. Ann Intern Med 2014; 160: 233-42. [CrossRef]

Publisert: 29. april 2014. Tidsskr Nor Legeforen. DOI: 10.4045/tidsskr.14.0351

(C) Tidsskrift for Den norske legeforening 2023. Lastet ned fra tidsskriftet.no 26. april 2023. 